\title{
Zrcadlo historické sociologie
}

Kdykoliv chceme někam vykročit, je třeba se nejprve jednou nohou pevně opřít o zem, druhou mírně nadzvednout a potom vyrazit. Do dálky i do výšky obvykle také nejlépe skáčou ti, kdo mají výborný odraz. Tím spíše to platí o našich editorialech, které se v minulosti nejednou odrážely od určitých, na první pohled konvenčních pojmů, aby se ukázalo, že mezi jejich fasetami se najde mnohé téma jako stvořené pro historickou sociologii. Přirozenými zrcadly našich mentálních i emočních pochodů jsou mimo jiné knihy. Kultura knihomolů odedávna předpokládala, že zbožné přání mnoha z nás, totiž dostat se alespoň dočasně mimo dějiny (a to zvláště v př́padě, kdy je doba náhle zasažena neobvyklými př́rodními úkazy a pohromami), naplňuje právě ústraní věnované četbě. Po jistý čas lze ale vydržet třeba jen ve vzpomínkách nebo se „zabavit“ vyprávěním příběhů.

Vybírám pro tuto chvíli ze své knihovny knihu německého romantického filozofa, estetika a literárního vědce Karla Wilhelma Fridricha von Schlegela (1772-1829) Geschichte der romantischen Literatur [1965]. A hned se začítám do úvah o italské novelistice, včetně kapitoly o Giovanni Boccacciovi (1313-1375) a jeho Dekameronu (s. 205-221). Když Schlegel uvažuje o podstatě novely, vychází z jejího sociálního zázemí. Vznik tohoto žánru byl podle něho spjat $s$ vývojem rafinovaného společenského života vzdělaných stavů, a proto si zvolí za hlavní námět anekdotu či drobný příběh (klep ze společnosti), jenž pro jednou nemá nic společného se vztahy národů a epoch, př́padně s pokrokem lidstva a jeho vzdělaností. Jde tedy o „příběh mimo dějiny“ - přímo v německém originále stojí: „Eine Geschichte also, die streng genommen, nicht zur Geschichte gehört.“

Aby se ovšem takto odlehčený nápad stal zajímavým, musí být obdařen půvabem ironie a duchaplnosti, anebo - což pokládá Schlegel za vyšší typ podání - musí nést pečet’ vypravěčovy osobnosti. Musí zrcadlit jeho vkus a povahu, čímž teprve získávají i známé historky nový význam. Schlegel tu v zásadě vyslovuje totéž co jiný idealistický romantik, totiž Friedrich Wilhelm Joseph von Schelling (1775-1854), že moderní próza dosahuje obecné významnosti nikoliv svou látkou, nýbrž způsobem podání. Vyprávění má rovněž podle Schellinga prozrazovat autorovu osobní zaujatost, naléhavost námětu, ba zasaženost vypravěče př́během. Genologicky řečeno, v novele vystupuje moment historičnosti značně oslabený a může odpadnout vůbec. Ostatně na „historii“ byly orientovány vždy spíše kroniky a žánry jim př́ibuzné.

Giovanni Boccaccio dokázal $\mathrm{z}$ hrubého tvaru novely vybudovat i díky promyšlené rétorice dokonalý literární útvar. Nezapomínejme však ani na folklorní základ lidové „humorky“. Ve folklórní tvorbě bývá podobně jako u Boccaccia silně akcentován lokální kolorit, jak ukazují již názvy takových děl či jejich částí. Základním rysem novely zůstává příběh, který mohl být ve své době zdánlivou novinkou, nebo dokonce senzační aférou. Novela by měla být ukončena neočekávanou pointou, celek dobrého novelistického textu se nadto vyznačuje soudržností, i když některé epizody mohou být libovolně vypouštěny. 
Geneze knižní novely potvrzuje význam folklorních anekdot, v nichž se dosti často objevují dva protichůdné póly, především chytrost a hloupost - postavy chytráků (šibalů) stojí proti hlupákům. Setkáváme se taktéž s porušováním elementární logiky. Absurdní paradox společně se situací, kdy je něco učiněno hloupým, respektive je to zesměšněno (stejný smysl má „sebezesměšněni“), otevírá dokořán brány ke specifickým pravidlům anekdoty. Další pozoruhodný rys se na tomto poli skrývá v uplatnění principu ambivalence, totiž že něco je „tak i tak“, obě možnosti platí zároveň. Situace bývá často modelována za pomoci „ostrého“ slova (hlavně v anekdotě), nebo morálky a mravního naučení (v bajce a kazatelském exemplu).

V evropských literaturách najdeme sbírky novel provázaných do společného celku jednou hlavní novelou, která vytváří příslušné zarámování čili „rámcování. Pokud jde o Dekameron, rámcová novela tu není navzájem spojena jednotou jednajících osob. Veškerá pozornost se zaměřuje na děj - jednající osoba se stává pouze jakousi etiketou, s nadsázkou řečeno „hrací kartou“. Tak v Dekameronu si po deset dní vypravuje roztodivné př́ihody sedm paní a tři jinoši, přičemž všichni tito vypravěči uprchli před morem (jde o morovou epidemii z roku 1348) z Florencie na venkov. Nebudeme tady konkrétně podávat obsahy jednotlivých př́běhů, jichž je v tomto sborníku novel, jak známo, celkem stovka. Zdůrazněme jen určité formální a stylistické poznámky. Např́klad se v tomto díle vyskytují parodie religiózních hagiografických motivů (viz I, 1; II, 2; III, 10). Týká se to především parodií na legendy o poustevnících, předmětem parodování jsou ale rovněž legendy o očistci. Do hry tudíž začasté vstupují vykonavatelé náboženského kultu, jmenovitě duchovenstvo $v$ podobě mnichů a kněží. Vidíme přitom jasně patrné úsilí syntetizovat vysoké a nízké žánry středověké literární hierarchie. Dále jsou v Dekameronu frekventovány úžeji zacílené motivy středověké nižší narativity, a to zejména erotické, $\mathrm{z}$ velké části spojené s elementy šibalství a klamu (viz II, 9; III, 1,2,4-7; VIII, 7,8; IX, 10), také jakoby šibalské (například I, 1; II, 5; VIII, 10), stejně tak se tu vyskytuje řada příběhů traktujících výsměch nad hloupostí.

Ideově a formálně leží Dekameron na rozhraní dvou kulturních a sociálních epoch. Novely obecně představují vedle mnoha jiných souvislostí i výraz myšlení nastupujícího měštanstva. Výrazně se v Boccacciově kompozičním plánu uplatňuje symbolika čísla deset. Pokud jde o „ducha doby“, dominuje zde utilitarismus a velká část novel je vybudována na námětu erotickém - vlastním účelem toposu odloučení zde není meditace, nýbrž poskytnutí prostoru k radosti a zábavě. Vyjadřuje se tu již svébytná renesanční morálka, včetně morálky konečného úspěchu, a to i za cenu lsti a klamu...

K žánru novely se v literárněhistorickém a literárněteoretickém kontextu výstižně vyjádřil ruský literární vědec, formalista Viktor Borisovič Šklovskij (1893-1984) ve svém souboru studií, Teorii prózy, poprvé vydaném roku 1925 (tř̌etí české vydání pochází z roku 2003). Ani v tomto př́ípadě nemůžeme jít příliš do hloubky a šířky novelistické tvorby, její kompozice a stylu. Nicméně nelze vyloučit závislost Dekameronu na předchozích latinských předlohách (viz Apuleius; Disciplina clericalis Petra Alfonsiho; Gesta Romanorum; Kronika sedmi mudrců). Literárně Boccaccio ovlivnil Markétu Navarrskou (1492-1549), jejíž sbírka novel Heptameron má následující děj - pět mužů a stejný počet žen se vrací z pyrenejských lázní, zastaví je povodeň, a když je stržen most, uchýlí se do kláštera, kde si každý den vyprávějí př́běhy. Během osmi dnů tak zazní 72 novel. Uvedená sbírka má samozřejmě francouzské reálie první poloviny 16. století. Nakonec ještě připomeňme 
Pentameron Giambattisty Basileho (1575-1632). Původním datem posthumního publikování jeho sestrou Adrianou byl rok 1634.

Odrazili jsme se důkladně, ale raději již dosti úvah kolem Giovanniho Boccaccia a jeho nesmrtelného díla. Ze stránek Dekameronu se tak jako tak nedozvíme, co vlastně dělali účastníci jednoho morového útěku po návratu do Florencie. Lze jen předpokládat, že epidemie nebyla zdaleka u konce, že pouze skončila krátká chvíle jejich pobytu „mimo dějiny“. Zůstává otázkou, nakolik je stále ještě možné se Boccacciem rozptylovat v této naší nečekané „koronavirové" době. Nebojme se přitom s odkazem na Boccaccia ani jisté lehkosti nutně se skicováním spojované (současná covidová situace se zatím profiluje spíše katastroficky až apokalypticky, dnešek není renesance a my čelíme pandemii).

Doufám, že čtenářky a čtenáři mých vstupních zamyšlení si zvykli, že takřka každý editorial má vždycky více či méně zřetelný šev. Chvíli trvá, než přikročíme ke stručné charakteristice právě vydávaného čísla Historické sociologie. Podotýkám, že toto číslo našeho periodika je dosti obsáhlé. Prošlo tak jako každé důkladnou oponenturou posuzovatelů i redakčními úpravami.

Značnou trpělivost $\mathrm{v}$ tomto smyslu projevil rovněž renomovaný historik aristokracie Jan Županič, který tu pojednal o sociálním vzestupu podnikatelů v éře Rakouského císařství. Sledoval mimo jiné trendy, kdy významnou roli mezi podnikateli hrála aristokracie, přičemž postihl i „aristokratizaci“ bohatých podnikatelů.

Důležité místo v dějinách sociologie náleží Paulu Lazarsfeldovi, který měl v únoru 2021 výročí 120 let od narození. Propagátor jeho díla Hynek Jeřábek tentokrát v našem periodiku posuzoval aktéry, mechanismy a okolnosti směřující k ustavení modelu empirického výzkumu, jež zavedla kolumbijská sociologická škola v Norsku v letech 1947-1955. Jeřábkův článek zachycuje Lazarsfeldův první evropský sabatikal v Oslu, jenž výrazně přispěl $\mathrm{k}$ procesu žádané institucionalizace empirické sociologie v Norsku.

Slovenský badatel Tomáš Profant $\mathrm{v}$ případě koloniálního rozvoje se $\mathrm{v}$ rozsáhlé studii věnuje široké paletě př́čin, diskurzu, kontinuity, jakož i následků. Postihuje mimo jiné debatu o tom, že kolonialismus neobsahoval jen násilí, ale měl i svou liberální stránku. Právě tato liberální forma koloniální vlády je srovnatelná $s$ dnešním rozvojovým vládnutím, a tak je potřebí rozvoj chápat jako prvek kolonialismu. Do hry vstupuje i problematika kontinuity a diskontinuity koloniální a postkoloniální éry.

Dále Jana Pumra zajímá třídně založené volební chování zvláště v rozvíjejících se západních zemích; třídní struktura představuje základnu pro třídní volební výzkum. Pumrova studie se to pokouší uplatnit na kolumbijském stratifikačním modelu.

Dvojice autorek Irena Cejpová a Andrea Štolfová si předsevzala bádat nad regionální identitou ve vztahu k zachování hmotného kulturního dědictví v pohraničním prostoru, konkrétně na Plzeňsku a v jižních Čechách. Přitom byly využity reprezentativní výsledky polostrukturovaných rozhovorů i vlastního pozorování.

Článek Terezy Čepilové zachycuje sociální faktory ovlivňující roli současných babiček z Pardubic a okolí. V potaz jsou brány rovněž nesnadno kvantifikovatelné, subjektivní, avšak pro ženy významné faktory utvářející jejich prarodičovskou funkci. Hloubkové rozhovory byly provedeny s babičkami dětí navštěvujících první třídy základní školy. V neposlední řadě působení a dopady zvolených faktorů na roli babičky jsou prezentovány na vykonávání dané role během posledních tři generací. 
Již standardně v našem žurnálu obsazují specifické místo taktéž žánry projekt nebo skica. Tak skica autora tohoto editorialu tu zachycuje kulturní a sociální dějiny pracovního prostředí do roku 1950. Ukazuje se, že teorie pracovního prostředí, techniky a technologií byla vždy diferencována mezi různými vědami a disciplínami. Obecně řečeno, člověk bývá během svého vývoje vystaven tlaku prostředí nejen př́rodního, nýbrž také toho „umělého“, pracovního, popř́ípadě „sídelního“ (tzv. bytová otázka). Dále na historickou situaci tehdy zapo̊sobila průmyslová výroba se svými továrními halami. V předložené skice se též pojednává o hygieně práce a chorobách z povolání. V úvahu se bere i tehdejší rozvoj technokratických tendencí. Povahu skici má rovněž příspěvek věnovaný dimenzím historické sociologie. Jde o krátký přehled problematiky, která má své místo nejen ve světovém měřítku, nýbrž i na Fakultě humanitních studií Univerzity Karlovy v Praze.

Co říci na závěr obvyklého editoriálního výstupu v tomto čísle. Každý čtoucí si může vyzkoušet větší nebo menší skicu k historicko-sociologické problematice a ukázat ji širšímu publiku v našem periodiku. Při různých př́ležitostech se zamýšlím: Chtělo by přijít s jednou průbojnou ideou, která by vytvořila proud blahodárného myšlení. Další možnosti by přinesl specifický rámec, do něhož by se vměstnaly myšlenky jiných. To je nejspíš velký sen, zůstaňme raději při zemi. Avšak jako vždy si přejme aktivní čtenářky a čtenáře našeho společného periodika Historická sociologie.

Bohuslav Šalanda

DOI: 10.14712/23363525.2021.1

\section{Literatura}

Auerbach, Erich [1968]. Mimesis. Zobrazení skutečnosti v západoevropských literaturách. Praha: Mladá fronta.

Boccaccio, Giovanni [2013]. Dekameron. Praha: Odeon.

Krejčí, Karel (ed.) [1974]. Př́íspěvky k morfologii a sémantice literárněvědných termínů. Praha: Ústav pro českou literaturu ČSAV.

Rotunda, Dominic Peter [1942]. Motif-Index of the Italian Novella in Prose. Bloomington: Indiana University Press.

Schlegel, August Wilhelm [1965]. Geschichte der romantischen Literatur. Stuttgart: Kohlhammer Verlag. Šklovskij, Viktor Borisovič [1978]. Próza. Úvahy a rozbory. Praha: Odeon.

Šklovskij, Viktor Borisovič [2003]. Teorie prózy. Praha: Akropolis. 